\title{
The Effect of Extract Bitter Melon and Snakehead Fish on Advanced Glycation End Products
}

\author{
Sari Amalia, MI. Diah Pramudianti, Yuwono Hadisuparto \\ Department of Clinical Pathology, Faculty of Medicine, Sebelas Maret University/Dr. Moewardi General Hospital, Surakarta, Indonesia. \\ E-mail:drsariamalia.sppk@gmail.com
}

\begin{abstract}
Type-2 Diabetes Mellitus (DM) is a transformation of insulin function in peripheral tissues or disorders of pancreatic $\beta$-cells. The combination of glycation and glucose oxidation in type 2 DM patients results in the formation of AGEs, which can result in oxidative stress. One of the attempts to reduce oxidative stress is the use of natural ingredients as a source of antioxidants. For example, bitter melon (Momordica Charantia) and snakehead fish (Channa Striata) extracts. The research about the combination of bitter melon and snakehead fish extracts to AGEs levels remains limited and has only been tested on Wistar rats and mice. This study aimed to determine the effect of the combination of bitter melon and snakehead fish extracts on AGEs levels in type-2 DM patients. This study was a clinical experimental randomized double-blind control trial performed at Purwosari Public Health Center, Surakarta, and AGEs levels were measured in the Clinical Pathology Laboratory of Dr. Moewardi Hospital, Surakarta from July to August 2020. Comparative analysis using the paired sample T-test was carried out due to the normal distribution of data, paired and numerical data. The $p<0.05$ was considered significant with a Confidence Interval (CI) of $95 \%$. A total of 40 subjects consisted of 20 pre- and 20 post-treatment. The results of the analysis test showed significant differences in AGEs levels in the pre- $\mathrm{pg} / \mathrm{mL}$ and the post-treatment with levels of 70.78 (53.47-321.93) and 39.91 (34.70-71.85) pg/mL $(p=0.001)$, respectively in the group that received the combination of bitter melon and snakehead fish extracts. There was an effect in AGEs levels after receiving the combination of bitter melon and snakehead fish extracts. It was concluded that the combination of both materials can be used as a supplement to reduce complications of type 2 diabetes. Further research was needed to specifically measure the AGEs products that have decreased.
\end{abstract}

Keywords: Momordica charantia, Channa striata, advanced glycation end products, type-2 diabetes mellitus

\section{INTRODUCTION}

Type-2 Diabetes Mellitus (DM) remains a world health problem in several countries, both in industrialized and developing countries due to the increasing prevalence and incidence. Therefore, in some developing countries, it is encouraged to improve people's healthy living behavior. The World Health Organization (WHO) predicts that the number of DM sufferers in Indonesia from 8.4 million in 2000 will be increased to approximately 21.3 million in 2030. According to the International Diabetes Federation (IDF), Indonesia is a country with the $2^{\text {nd }}$ highest diabetes case. It is estimated that there will be 10.6 million DM cases in the age range of 20-79 years worldwide. ${ }^{1,2}$

The combination of glycation and glucose oxidation in type 2 DM patients results in the formation of Advanced Glycation End Products (AGEs), which can cause oxidative stress. Increased oxidative stress is followed by increase in free radicals, which results in an increased lipid peroxidation, which then also activates the formation of AGEs. ${ }^{3}$ Excessive accumulation of AGEs in tissues is found in DM patients, and AGEs play a relevant role in tissue changes and clinical complications associated with this disease. The increase in AGEs levels is due to an increase in dicarbonyl precursors, such as methylglyoxal, malondialdehyde, and 3-deoxyglucosone. Elevated levels of AGEs correlate with peripheral and autonomic neuropathy with neuropathic foot ulcers and may exacerbate ulceration and endothelial dysfunction in diabetic neuropathic patients. ${ }^{4}$

Attempts to minimize complications need to be carried out in patients with type $2 \mathrm{DM}$ to reduce oxidative stress, one of which is by the use of natural ingredients as a source of antioxidants, such as bitter melon fruit (Momordica charantia), and snakehead fish (Channa striata) extract in improving 
hyperglycemic conditions. ${ }^{5-7}$ Bitter melon can inhibit the carbonyl group in the formation of AGEs and increase insulin sensitivity and lipolysis. ${ }^{8}$ In addition, several studies have shown that the hypoglycemic effect of bitter melon is comparable to oral drugs such as tolbutamide, chlorpropamide, and glibenclamide. ${ }^{9}$ Administration of snakehead fish extract against Wistar, which has been induced by alloxan can regenerate pancreatic islets of Langerhans tissue and succeeded in reducing blood glucose levels by $34.42 \%{ }^{10}$ Snakehead fish extract given in a dose of $30 \mathrm{mg} / \mathrm{Kg} /$ day can act as an antioxidant by reducing the level of oxidative stress. ${ }^{11}$

Based on the background, increasing levels of AGEs can increase oxidative stress, which triggers type-2 DM complications. In addition to the limited study on the combination of bitter melon and snakehead fish extract to AGEs levels and its mere test on Wistar rats and mice, administration of a combination of bitter melon extract and snakehead fish is expected to reduce AGEs levels in type-2 DM patients. Therefore, the authors aimed to analyze the effect of bitter melon and snakehead fish extract on patients with type 2 diabetes to analyze the AGEs levels before and after administration.

\section{METHODS}

An experimental research design was used in this study. This research was conducted with initial measurement (pre-test) and final measurement (post-test). Subjects in this study were divided into two groups such as the standard therapy group and the group of standard therapy with administration of the extract. The standard therapy group consisted of 20 subjects administrated with only glibenclamide $2 \times 5 \mathrm{mg}$ and metformin $1 \times 500 \mathrm{mg}$ without the addition of a combination of $300 \mathrm{mg}$ bitter melon and $300 \mathrm{mg}$ snakehead fish extract, whereas the group of standard therapy with extract also consisted of 20 subjects administrated with glibenclamide $2 \times 5 \mathrm{mg}$ and metformin $1 \times 500 \mathrm{mg}$ and a combination of $300 \mathrm{mg}$ bitter melon and $300 \mathrm{mg}$ snakehead fish extract.

The study was performed at the Purwosari Health Center in Surakarta and tested at the Clinical Pathology Laboratory Installation of the RSDM in Surakarta from July to August 2020. The target population of this study was type-2 DM patients. Research subjects in this study were selected by simple random sampling. The inclusion criteria of research subjects included male and female patients with type- 2 diabetes, age $>18$ years, willingness to participate in the study, and signing the informed consent. Exclusion criteria for research subjects included patients with a history of macrovascular complications of DM and allergies to bitter melon and snakehead fish extract based on the anamnesis or medical records. Drop-out criteria included patients with complaints of allergic reactions related to bitter melon extract and snakehead fish as side effects during the administration period, discontinuation of drugs, early resignation, worsening conditions, or death.

Serum was used as the sample in this study and AGEs levels were measured using the ELISA method (Raito RT-2100 C) with a unit value of $\mathrm{pg} / \mathrm{mL}$. The reagent kit material of Human AGEs ELISA kit (96 tests) from MyBioSource, United States of America (USA), San Diego was used. ${ }^{12}$

Data on the characteristics of gender, age, Body Mass Index (BMI) of long-suffering from DM and $\mathrm{HbAlc}$ of research subjects were presented in analytical form. The basic variables were described as mean and Standard Deviation (SD). Shapiro-Wilk test ( $p$ means $>0.05$ ) was used for the statistical analysis of the data with a sample of $<50$. To analyze the mean difference between groups, the independent sample T-test was used for normally distributed data, while the Mann-Whitney test was used for data with the abnormal distribution. To determine the mean of pre and post-therapy in one group, paired T-test or paired sample T-test was used for data with normal distribution, while the Wilcoxon test was used for data with the abnormal distribution. The data was processed using a computer statistical program to determine the $p$-value $<0.05$ with a $95 \%$ confidence level.

This research had received approval from the Health Research Ethics Committee of the Dr. Moewardi Hospital with number 934/VII/ HREC/2020.

\section{RESULTS AND DISCUSSIONS}

The characteristics of the research subjects analyzed in this study consisted of gender, age, BMI, length of DM, and $\mathrm{HbA1C}$ of a total of 40 subjects. Based on the characteristic of gender, 20 subjects in the standard therapy group consisted of 17 (85\%) females and $3(15 \%)$ males, while 20 subjects in the group of standard therapy with extracts consisted of $10(50 \%)$ females and $10(50 \%)$ males $(p=0.020)$, indicating a significant difference in the number of samples based on gender in both groups (Table 1). These results were following the results of the Riskesdas in 2018, which found that DM patients in Indonesia were $1.8 \%$ females $>1.2 \%$ males. Similar 
results were also obtained in African, North African, South American, and Central American countries. The higher percentage of females suffering from diabetes is due to an increase in the hormone testosterone during menopause, resulting in an increased visceral fat deposition, which will be a risk for type-2 diabetes. Increased testosterone levels result in the activated androgen receptor in the pancreatic beta-cell leading to diabetes. ${ }^{13}$

Based on the characteristics of age, the average age in the standard therapy group and the standard therapy group with study extract was $63.75 \pm 9.43$ years and $65.45 \pm 6.75$ years $(p=0.516)$, respectively indicating no significant age difference between both groups (Table 1). These results were in accordance with results by Riskesdas in 2018, which found the most type-2 DM patients were at the age between $55-64$ years (6.3\%) followed by age between $65-74$ years (6.0\%). The cause of a large number of people with type $2 \mathrm{DM}$ in this age range is due to hormonal disorders and high consumption of alcoholic beverages. ${ }^{14-17}$ Consumption of alcoholic beverages can cause people at risk of diabetes due to their ability to interfere with liver function to store glucose as glycogen, increase appetite toward unhealthy foods that have the potential to be obese, and interfere with insulin sensitivity. ${ }^{18-20}$

Based on the characteristics of BMI, the average BMI in the standard therapy group and the standard therapy group with test material was $24.69 \pm 3.84$ $\mathrm{kg} / \mathrm{m}^{2}$ and $25.31 \pm 3.87 \mathrm{~kg} / \mathrm{m}^{2}(\mathrm{p}=0.612)$, respectively indicating no significant differences in BMI between both groups (Table 1). These results were in accordance with the results by PERKENI in 2019, which found that the group with excess body weight with BMI of $23 \mathrm{~kg} / \mathrm{m}^{2}$ was at risk of type-2 DM.
According to the CDC in 2020, about $89 \%$ of people with diabetes are overweight $\left(B M I=25-29.9 \mathrm{~kg} / \mathrm{m}^{2}\right){ }^{21}$

Based on the characteristics of length of $D M$, the median value (min-max) in the standard therapy group and the standard therapy group with test materials were $7.50(5-10)$ years and $8.50(5-24)$ years $(p=0.136)$, respectively suggesting no significant difference in the length of DM between both groups (Table 1). This was in line with research by Raghavendran et al., which found that $40.5 \%$ of subjects in India had suffered from type 2 DM for 6-10 years. In addition, research in Turkey in 2019 also found that there were $47.9 \%$ and $31.7 \%$ subjects who had suffered type 2 DM above 9 years and 6-9 years, respectively. ${ }^{22,23}$

Based on the characteristics of HbAlc, the average $\mathrm{HbA1c}$ levels in the standard therapy group and the group of standard therapy with extract was $8.50(5.20-14.20) \%$ and $8.80(6.40-15.80) \%(p=0.588)$, respectively indicating no significant difference in HbA1c levels between both groups (Table 1 ). These results were in accordance with the results by PERKENI in 2019 suggesting that HbA1c test with a standardized method and a value of $6.5 \%$ (uncontrolled diabetes for 3 months) is used as one of the criteria for the diagnosis of type $2 \mathrm{DM}$ and to determine therapy and escalation of therapy. A study in China in 2019 found irregular HbA1c values using basal insulin on average of $9.9 \pm 2.0 \%$ and regular $\mathrm{HbA1c}$ using basal insulin therapy on average of $9.5 \pm 2.0 \% .^{24}$

The results of the analysis test for the comparison of pre- and post- AGEs levels in the standard therapy group showed pre-AGEs levels of 37.47 (30.27-53.49) $\mathrm{pg} / \mathrm{mL}$ and post-AGEs levels of 40.92 (31.49-48.39) $\mathrm{pg} / \mathrm{mL}(\mathrm{p}=0.021)$, suggesting a significant difference in

Table 1. Basic characteristics of research subjects

\begin{tabular}{|c|c|c|c|c|c|}
\hline \multirow{2}{*}{ Variable } & \multicolumn{2}{|c|}{ Standard Therapy $(n=20)$} & \multicolumn{2}{|c|}{$\begin{array}{c}\text { Standard Therapy+Test } \\
\text { Materials }(n=20)\end{array}$} & \multirow[t]{2}{*}{$\mathbf{P}$} \\
\hline & Total n(\%) & Mean & Total n(\%) & Mean & \\
\hline \multicolumn{6}{|l|}{ Gender } \\
\hline Male & $3(15 \%)$ & & $10(50)$ & & 0.020 \\
\hline Female & 17 (85\%) & & $10(50)$ & & 0.020 \\
\hline Age (years) & & $63.75 \pm 9.43^{*}$ & & $65.45 \pm 6.75^{*}$ & 0.516 \\
\hline BMI $\left(\mathrm{kg} / \mathrm{m}^{2}\right)$ & & $24.69 \pm 3.84^{*}$ & & $25.31 \pm 3.87^{*}$ & 0.612 \\
\hline Length of DM (years) & & $7.50(5-10)^{\star \star}$ & & $8.50(5-24)^{\star \star}$ & 0.136 \\
\hline HbA1c (\%) & & $8.50(5.20-14.20)^{* *}$ & & $8.80(6.40-15.80)^{* *}$ & 0.588 \\
\hline
\end{tabular}

Note : Mean value * = normal distribution (mean \pm SD), independent sample T-test, ${ }^{* *}=$ abnormal distribution, [Median (min-max)], Mann-Whitney test, $\mathrm{n}=$ total of research subjects, min-max= minimum-maximum, BMI: Body Mass Index, DM: Diabetes Mellitus, kg: kilogram, $\mathrm{m}^{2}$ : meter square, $\mathrm{HbA} 1 \mathrm{c}$ : hemoglobin $\mathrm{A} 1 \mathrm{c}, \mathrm{p}<0.05$ significant, $\mathrm{CI}=$ Confidence Interval of $95 \%$ 
the levels of pre- and post-treatment AGEs in the standard therapy group (Table 2). Analysis test results for comparison of pre- and post-treatment AGEs levels in the group of standard therapy with the extract showed pre-AGEs levels of 70.78 (53.47-321.93) pg/mL and post-AGEs levels of 39.91 (34.70-71.85) pg/mL $(p=0.001)$, indicating a significant difference in the levels of pre-and post-treatment AGEs in the group of standard therapy with the extract (Table 3 ).

The results of the comparison analysis of delta AGEs before and after treatment in the standard therapy group and the group of standard therapy with the extract showed a mean value of $3.24 \pm 5.59$ $\mathrm{pg} / \mathrm{mL}$ and $(-17.13) \pm 14.68 \mathrm{pg} / \mathrm{mL} \quad(p=0.001)$, respectively indicating a significant difference in the levels of delta AGEs in both groups (Table 4). The average result of the delta variable in the group of standard therapy with the test material was negative, suggesting a significant decrease in AGEs levels. This means that standard therapy with a combination of bitter melon and snakehead fish extract can provide benefits to reduce AGEs levels, thereby reducing the risk of complications of type $2 \mathrm{DM}$.

This study was in accordance with Aljohi et al. that bitter melon extract has many amino acids that inhibit carbonyl groups during the protein glycation process. According to Wang and Ryu who researched on bitter melon extract on mice, it was found that bitter melon extract can reduce lipid peroxidation. Research by Suhendi et al. using snakehead fish extract on Wistar found that albumin in snakehead fish can inhibit lipid peroxidation. ${ }^{25}$ The research by Muhtadi and Pangestuti in 2019 using extracts of bitter melon and snakehead fish on hyperglycemic rats found that the combination of ethanol extract of bitter melon at a dose of 300 $\mathrm{mg} / \mathrm{kg} \mathrm{BW}$ and snakehead fish powder at a dose of $300 \mathrm{mg} / \mathrm{kg}$ BW could lower blood sugar levels higher than administration of ethanol extract of bitter melon, and $300 \mathrm{mg} / \mathrm{kg}$ BW and snakehead fish powder $300 \mathrm{mg} / \mathrm{kg} \mathrm{BW}$ single. ${ }^{26}$ This study tried the same thing but with human subjects with type $2 \mathrm{DM}$

Table 2. Comparison of pre- and post-treatment AGEs levels in the standard therapy group

\begin{tabular}{|c|c|c|c|}
\hline \multicolumn{4}{|c|}{ Standard Therapy Group } \\
\hline \multirow{2}{*}{ Variable } & Pre & Post & \multirow{2}{*}{$\mathbf{p}$} \\
\hline & Mean \pm SD & Mean \pm SD & \\
\hline AGEs (pg/mL) & $37.47(30.27-53.49)^{*}$ & $40.92(31.49-48.39)^{*}$ & 0.021 \\
\hline
\end{tabular}

Note: Mean * abnormal distribution, [Median (min-max)], Wilcoxon test, min-max= minimum-maximum, SD=Standard Deviation, AGEs: Advanced Glycation End Products, SD: Standard Deviation, pg: picogram, mL: mililitre, $p<0.05$ significant, $\mathrm{CI}=$ Confidence Interval of $95 \%$

Table 3. Comparison of pre- and post-treatment ages levels in the group of standard therapy with test material

\begin{tabular}{|c|c|c|c|c|c|c|c|}
\hline \multicolumn{8}{|c|}{ Group of Standard Therapy+Test Material } \\
\hline \multirow[t]{2}{*}{ Variable } & \multicolumn{2}{|c|}{ Pre } & \multicolumn{3}{|c|}{ Post } & \multirow{2}{*}{\multicolumn{2}{|c|}{$\mathbf{p}$}} \\
\hline & \multicolumn{3}{|c|}{ Mean $\pm S D$} & \multicolumn{2}{|l|}{ Mean $\pm S D$} & & \\
\hline AGEs (pg/mL) & \multicolumn{3}{|c|}{$70.78(53.47-321.93)^{\star}$} & \multicolumn{2}{|c|}{$39.91(34.70-71.85)^{*}$} & \multicolumn{2}{|c|}{0.001} \\
\hline \multicolumn{8}{|c|}{$\begin{array}{l}\text { Note: Mean * }{ }^{*} \text { abnormal distribution, [Median (min-max)], Wilcoxon test, min-max }=\text { minimum-maximum, } S \mathrm{D}=\text { Standarc } \\
\text { Deviation, AGEs: Advanced Glycation End Products, SD: Standard Deviation, pg: picogram, mL: mililitre, } \mathrm{p}<0.05 \text { was } \\
\text { significant, CI=Confidence Interval of } 95 \%\end{array}$} \\
\hline \multirow{2}{*}{ Variable } & \multicolumn{3}{|c|}{ Standard Therapy Group } & \multicolumn{3}{|c|}{$\begin{array}{c}\text { Group of Standard Therapy with } \\
\text { Test Material }\end{array}$} & \multirow{2}{*}{$\mathbf{p}$} \\
\hline & Mean & Min & Max & Mean & Min & Max & \\
\hline Delta AGEs (pg/mL) & $3.24 \pm 5.59^{\star}$ & -6.48 & 11.99 & $-17.13 \pm 14.68^{*}$ & -39.37 & 11.98 & 0.001 \\
\hline
\end{tabular}

Note: Mean value * = normal distribution (mean \pm SD), Independent sample T-test, min-max= minimum-maximum, AGEs: Advanced Glycation End Products, SD: Standard Deviation, pg: picogram, mL: millilitre, $p<0.05$ was significant, $\mathrm{CI}=$ Confidence Interval of $95 \%$ 
who received standard therapy with a combination of $300 \mathrm{mg}$ bitter melon extract and $300 \mathrm{mg}$ snakehead fish extract. In addition, this study found a significant decrease in serum AGEs levels. The strength of this study was the use of the experimental design on humans that have previously been carried out on animals, thereby adding a reference on the causal relationship to the use of bitter melon and snakehead fish extract, especially in type 2 DM patients. The limitations of this study include the lack of references using human subjects related to this study due to the mere use of animal subjects in most studies. However, there was no reference value of AGEs levels in this study, that this study was unable to provide an overview of AGEs levels that are at risk for complications of type $2 \mathrm{DM}$. This study has not been able to measure specifically the types of the AGEs product, including CML, CEL, pyrraline, or pentosidine which have decreased. The study was only carried out at one center that it was unable to determine any differences at different centers.

\section{CONCLUSIONS AND SUGGESTIONS}

Based on the results of this study, it was concluded that there was an effect of combination between bitter melon and snakehead fish extract proven by a significant decrease in AGEs levels in type 2 DM patients $(p=0.001)$. The combination of bitter melon and snakehead fish extract can be used as a supplement to reduce the occurrence of complications of type $2 \mathrm{DM}$.

Futher research is needed to specifically measure the parts of AGEs products that have decreased including, $C M L, C E L$, pyrraline or pentosidine.

\section{REFERENCES}

1. Decroli E. Diabetes melitus tipe 2. Padang, Pusat Penerbitan Bagian Ilmu Penyakit Dalam Fakultas Kedokteran Universitas Andalas, 2019; 2.

2. PERKENI. Konsesus pengelolaan dan pencegahan diabetes melitus tipe 2 di Indonesia 2019. Jakarta, PB PERKENI, 2019; 3.

3. Subandrate. Hubungan kadar glukosa darah dengan peroksidasi lipid pada pasien diabetes melitus tipe 2 . Palembang, CDK-242, 2016; 43(7): 2-3

4. Jud P, Sourij H. Therapeutic options to reduce advanced glycation end products in patients with diabetes mellitus: A review. Diabetes Research and Clinical Practice Elsevier B.V, 2018; 148: 54-63.

5. Phimarn W, Sunthong B, Saramunee K, Caichompoo W. Efficacy of Momordica charantia L. on blood glucose, blood lipid, and body weight: A meta-analysis of randomized controlled trials. Pharmacognosy Magazine, 2018; 14(56): 2-3

6. Chanda R, Samadder A, Banerjee J. Anti-diabetic activity of Momordica charantia or bitter melon: A Review. Acta Scientific Pharmaceutical Sciences, 2019; 3(5): 2581-5423.

7. Ningrum D, Abdulgani N. Pengaruh pemberian ekstrak ikan gabus (Channa striata) pada struktur histologi hati mencit (Mus musculus) hiperglikemik. Jurnal Sains dan Seni Pomits, 2014; 2(1): 2337-3520.

8. Aljohi A, Matou-Nasri S, Ahmed N. Antiglycation and antioxidant properties of Momordica charantia. PLos One, 2016; 11(8): 1-14.

9. Kumari S, Dash I, Behera K. Therapeutic effect of Momordica charantia on blood glucose, lipid profile and oxidative stress in type 2 diabetes mellitus patients: A randomised controlled trial. Journal of Clinical and Diagnostic Research, 2018; 12(9): 1.

10. Soniya F, Fauziah M. Efektivitas ekstrak ikan gabus sebagai antihiperglikemik. Jurnal Penelitian Perawat Profesional, 2020; 2(1): 2.

11. Sunarno. Potential of glutathione antioxidant in the hippocampus repair: preliminary study on bioactive materials antiaging of snakehead fish (Channa striata) in animal models of aging. Internat. J. Sci. Eng, 2015; 8(1): 25

12. Anonim. Human advanced glycation end products (AGEs) ELISA kit. Instruction version r09.3.1. 2020; Cat No. MHBS267540.

13. Xu W, Morford J, Mauvais-jarvis F. Emerging role of testosteron in pancreatic ?-cell function and insulin secretion. Journal of Endocrinology, 2019; 240(3): R97-R105.

14. Zhu H, Wang N, Han B, Li Q, Chen Y, Zhu C, Chen Y, et al. Low Sex hormone-binding globulin levels associate with prediabetes in chinese men independent of total testosterone. PLos One, 2016; 11(9): 6-10.

15. Kautzky-willer A, Harreiter J, Pacini D. Sex and gender differences in risk, pathophysiology and complications of type 2 diabetes mellitus. Endocrine Reviews, 2016; 37(3): 278-316.

16. Asiimwe D, Mauti G, Kiconco R. Prevalence and risk factors assocciated with type 2 diabetes elderly patients aged $45-80$ years at Kanungu district. Journal of Diabetes Research, 2020; 2020: 1-5.

17. Riset Kesehatan Dasar (RISKESDAS). Hasil utama RISKESDAS 2018. Jakarta, Badan Penelitian dan Pengembangan Kesehatan, 2018; 46-48.

18. Ambardekar N. Diabetes and alcohol. 2019. Available at: https://www.webmd.com/diabetes/guide/ drinking-alcohol (accessed 27 September, 2020).

19. Falck S. Diabetes, alcohol, and social drinking. 2019. Available at: https://www.healthline.com/health/ type-2-diabetes/facts-diabetes-alcohol (accessed 27 September, 2020).

20. American Addiction Centers. Alcohol use among diabetics: increased risk \& treatment complications. 2020. Available at: https://www.alcohol.org/ 
comorbid/diabetes-and-alcoholism (accessed 27 September, 2020).

21. Center for Disease Control and Prevention (CDC). Estimates of diabetes and its burden in the United States. National Diabetes Statistics Report, 2020; 1-30.

22. Soylar P, Kadioglu B. Kilic K. Investigation of the barriers about insulin therapy in patients with type 2 diabetes. Nigerian Journal of Clinical Practice, 2020; 23(1): 98-102.

23. Raghavendran S, Inbaraj L, Norman G. Reason for refusal of insulin therapy among type 2 diabetes mellitus patients in primary care clinic in Bangalore. Journal of Family Medicine and Primary Care, 2020; 9(2): 854-8.
24. Zhang $\mathrm{P}$, Zhang $\mathrm{H}$, Li X, Chen $\mathrm{M}$, Wang D, Ji L. Factors and outcomes associated with discontinuation of basal insulin therapy in patients with type 2 diabetes mellitus. Endocrinol Diab Metab, 2020; 3: 1-10.

25. Suhendi A, Muhtadi M, Sutrisna EM. Anti-inflammatory and antidiabetic of Channa striata powder and Nephelium lappaceum fruit peel ethanolic extracts on albino wistar mice. Drug Invention Today, 2019; 12(11): 2472-75.

26. Muhtadi, Pangestuti. Aktivitas antidiabetes dari kombinasi ikan gabus (Channa striata) dan ekstrak etanol buah pare (Momordica charantia L.) terhadap tikus wistar jantan yang diinduksi aloksan. University Research Colloqium, 2019; 40-47. 